УДК 37.091.4:37.091.33-028.17

DOI: 10.37026/2520-6427-2021-106-2-127-131
Володимир ОМЕЛЬЧУК,

кандидат педагогічних наук, доиент ВСП «Дубенський педагогічний фаховий коледж Рівненського державного гуманітарного університету».

м. Дубно, Україна

ORCID: 0000-0001-5935-1057

e-mail:vol.omelchuk@gmail.com

\title{
ПСИХОЛОГО-ДИДАКТИЧНІ ОСОБЛИВОСТІ УРОКУ В СУЧАСНІЙ ПОЧАТКОВІЙ ШКОЛІ В КОНТЕКСТІ ПЕДАГОГІЧНИХ ІДЕЙ ВАСИЛЯ СУХОМЛИНСЬКОГО
}

\begin{abstract}
Анотація. У статті розглядається проблема організачійних форм навчання, серед яких ключова роль відведена уроку, який і сьогодні, в умовах Нової української школи, забезпечує вирішення важливих освітніх завдань. Схарактеризовано зміни в типології та структурі сучасних уроків, застосування новітніх засобів $i$ технологій навчання.

Особливу увагу закиентовано на важливості використання педагогічних ідей та поглядів Василя Сухомлинського в сучасній школі. 3'ясовано, що урок як дидактична категорія загалом та методика його проведення зокрема посідає одне з ключових місиь у педагогічній системі видатного педагога, який
\end{abstract}

особливу увагу приділяв удосконаленню освітнього проиесу в початкових класах шляхом внесення корективів та психолого-дидактичних порад до проведення уроків; визначив структуру уроків, їхні дидактичні принципи, а також методи та завдання. Важливу роль відведено психологічній культурі вчителя, очінюванню знань учнів, а також подорожам, спостереженням і особливо досвіду проведення уроків у Школі під блакитним небом та в Школі радості. Зроблено висновок, щз найкращчии урок - той, який пробуджує не тільки розум дитини, а й торкається ї̈ серия.

Ключові слова: урок, освіта, навчання, розвиток, компетентність, екскурсія.

Volodymyr OMELCHUK,

PhD in Pedagogy, Associate Professor,

Dubno Applied Pedagogical College

of Rivne State Humanitarian University,

Dubno, Ukraine

ORCID: 0000-0001-5935-1057

e-mail:vol.omelchuk@gmail.com

\section{PSYCHOLOGICAL AND DIDACTIC FEATURES OF THE LESSON IN A MODERN PRIMARY SCHOOL IN THE CONTEXT OF VASYL SUKHOMLYNSKY'S PEDAGOGICAL IDEAS}

\begin{abstract}
Summary. The article deals with the problem of organizational forms of education, in particular the lesson which provides the solution of educational problems. Particular attention is paid to the importance of using Vasyl Sukhomlynsky's pedagogical ideas in solving this problem.

In the conditions of the implementation of the main provisions of the Concept of the New Ukrainian School and the law of Ukraine "On Education» the problem of preparing teachers for work in primary school today becomes especially actual. After all, the professional destiny of the student leaving general-educational schools is largely decided in a primary school, where the foundations of mathematical, philological, natural and artistic competence are laid. The challenges pedagogical institutions and Ukrainian teachers face today are quite complex. They make new demands on three main didactic categories: the content of education, teaching methods and organizational forms of learning.
\end{abstract}

Among these three didactic categories it is necessary and important to single out the one that ensures the implementation of the semantic and operational-psychological components of the learning process. This is a lesson.

In the conditions of NUS the problem of a lesson is defined as one of the main ones. The lesson as a didactic category the method of its implementation occupy one of the main places in Vasyl Sukhomlynsky's pedagogical system.

He saw one of his tasks as improving the educational process by making adjustments psychological and didactic advice for the lessons.

Based on the lessons attended and analyzed in primary school, Vasyl Sukhomlynsky defined there structure, didactic principles, methods and tasks.

The lesson has always been the central subject of Vasyl Sukhomlynsky's professional attention and care. He 
believed that attending and analyzing lessons are the most important dutis of the school principal.

Vasyl Sukhomlynsky paid special attention to the psychological culture of a teacher during the lesson.

The experience of conducting a lesson under the blue sky deserves special attention today.

Underestimation of Vasyl Sukhomlynsky's psychological and didactic advice significantly limits the educational opportunities of the lesson in modern primary school. The pedagogical experience of the famous teacher requires special attention and tolerant, wise implementation.

Key words: lesson, education, learning, development, competence, excursion.

Постановка проблеми. В умовах реалізації основних положень Концепції «Нова українська школа» (2016) та Закону України «Про освіту» (2017) проблема підготовки вчителя до роботи в школі, зокрема i в початковій, набуває нині неабиякої актуальності, адже саме в початкових класах закладаються основи математичної, філологічної, природничої та художньої компетентностей випускника закладу загальної середньої освіти.

Виклики, які постають сьогодні перед педагогічними закладами освіти, українським учительством загалом досить непрості. Вони висувають нові вимоги, що стосуються трьох основних дидактичних категорій: змісту освіти, методів навчання та організаційних форм навчання, які можна представити у вигляді запитань: «Чому навчати?», «Як навчати?» та «Які організаційні форми застосовувати?». Сьогодні саме ці дидактичні категорії стали предметом численних освітянських дискусій. Однак серед них необхідно виокремити ту, що забезпечує реалізацію змістового й операційно-технологічного компонентів процесу навчання. Цією категорією, звичайно, є урок - основна й незмінна форма навчання в школі, жива клітина освітнього процесу.

Урок - те місце, де відбуваються основні процеси навчання, виховання й розвитку особистості. 3 уроку починається розвиток конкретної школи та й усе життя в школі зазвичай протікає на уроках. Урок - це своєрідна морально-професійна візитівка учителя. Він повинен стати основним об'єктом моніторингу професійної діяльності кожного учителя. Як театр починається 3 гардеробу, так і школа починається з уроку. Від уроку залежить надзвичайно багато, зокрема культура, доброзичливість у взаєминах між учнями, учителями і батьками (Омельчук, 2018, с. 64).

Сьогодні відбуваються значні зміни у змісті освіти, типології та структурі уроків, з'являються новітні засоби і технології навчання, змінюється психологія молодших школярів. Однак авторитет уроку залишається незмінним та не піддається жодним сумнівам: які б не відбувалися реформи, урок, як і раніше, залишається основною формою навчання. На ньому трималася традиційна школа й розвивається сучасна. За роки свого навчання в школі учень відвідує понад десять тисяч уроків; уроку, його підготовці та проведенню присвячено не менше ніж $98 \%$ робочого часу вчителя. Сучасний урок - це передусім урок, спрямований на створення реальних умов для інтелектуального, соціального та морального становлення особистості учня.
Урок, як відомо, починається з учителя. Яким ж рисами має бути сьогодні наділений учитель початкових класів, щоб провести досконалий урок - урок доброти, гідності, любові, толерантності та оптимізму?

Щоб зрозуміти, якими мають бути сьогодні Нова українська школа й український учитель, а також те, як підготувати досконалий урок, необхідно звернутися до педагогічної системи Василя Сухомлинського. На нашу думку, сучасна українська школа та сучасний урок передусім потребують олюднення знань і освітнього середовища, це має бути школа гуманності, сердечності, любові, людяності, чуйності, толерантності та справедливості. А це можливо за умови активного використання українським учительством ідей гуманної педагогіки Василя Олександровича Сухомлинського (Омельчук, 2018, с. 6).

Аналіз наукових досліджень і публікацій. Окреслена нами проблема для психолого-педагогічної науки не $\epsilon$ новою. До неї у своїх дослідженнях зверталися чимало видатних філософів, педагогів, психологів, зокрема: Сократ (родоначальник евристичної форми навчання); Аристотель (уперше визначив необхідність урахування вікових, психологічних особливостей дітей у процесі навчання); М. Квінтіліан (обгрунтував необхідність індивідуалізації навчання); Ф. Рабле (був прихильником навчання дітей без покарання і примусу, а на основі зацікавленості й активності); А. Коменський (уперше з наукової точки зору обгрунтував класно-урочну форму навчання та основні принципи іiі реалізації); Й. Песталоцці (уперше диференціював змістову і розвиваючі сторони освітнього процесу); Д. Дьюї (уперше довів необхідність інтегрованих занять у початковій школі); М. Монтессорі (головною формою навчання вважала самостійні індивідуальні заняття дітей) та інші.

Заслуговують на увагу дидактичні поради Р. Кузіне та С. Френе, творців «вільної групової роботи»; Р. Штайнера, автора концепції розвитку людини; Л. Занкова, творця принципів розвиваючого навчання, що забезпечують ефективність освітнього процесу; К. Ушинського, прихильника класно-урочної системи організації навчальних занять у школі; Г. Ващенка, автора праці «Організаційні форми навчання».

Дидактично-психологічні поради, ідеї В. Сухомлинського щодо організаційних форм навчання у початковій школі - це одна з умов реалізацій основних положень Концепції Нової української школи. Цій вкрай важливій проблемі присвячено низку наукових статей та публікацій, які викликають неабиякий інтерес і стали предметом численних освітянських дискусій (М. Антонець, Л. Бондар, В. Василенко, В. Годлевська, Н. Калініченко, В. Омельчук, 3. Онишків, В. Риндак, О. Савченко, О. Коломійченко, Л. Норенко, О. Дмітрієва, О. Жадан, I. Максименко, С. Ручко та багато інших).

Серед послідовників гуманної педагогіки Василя Сухомлинського Ш. Амонашвілі, який радив учителям перетворювати шкільні заняття в «уроки щастя життя», пізнання, дорослішання; С. Лисенкова, уроки якої співзвучні з дидактичними принципами видатного педагога, адже на них «на все і на всіх вистачає часу»; С. Логачевська, яка розробила й зреалізувала унікальну методику диференційованого навчання молодших школярів. 
Незважаючи на значну кількість наукових публікацій, присвячених педагогічним ідеям і поглядам В. Сухомлинського, роздумам і порадам видатного педагога, висвітленим у працях «Серце віддаю дітям», «Розмова $з$ молодим директором школи», «Сто порад учителеві», «Павлиська середня школа» та ін., проблема впровадження його гуманної педагогіки, зокрема дидактично-психологічних порад, і сьогодні не втрачає своєї актуальності, потребує системного узагальнення й упровадження в практичне життя сучасної початкової школи.

Мета статті - висвітлити основні психолого-дидактичні особливості уроку в педагогічній спадщині Василя Сухомлинського з погляду сьогодення; окреслити шляхи, що впливають на ефективність освітнього процесу в сучасній початковій школі.

Зважаючи на мету дослідження, його основними завданнями $\epsilon$ : розкриття ролі та місця уроку в реалізації освітньо-виховних завдань сучасної школи; аналіз шляхів підвищення ефективності уроку в контексті психолого-дидактичних ідей і порад В. О. Сухомлинського.

Виклад основного матеріалу дослідження. Уроку як дидактичній категорії загалом і методиці його проведення зокрема в педагогічній системі Василя Сухомлинського відведено ключову роль. У зв'язку 3 цим видатний педагог писав: «Урок - це не тільки і не стільки те, що вичитав учитель напередодні своєї зустрічі з учнями з посібників і додаткової літератури. Урок - це дзеркало загальної і педагогічної культури учителя, мірило його інтелектуального багатства, показник його кругозору, ерудиції) (Сухомлинський, 1977, Т. 4, с. 580). У Павлиській школі урок завжди був предметом дискусій та обговорень на засіданнях педагогічної ради. Завуч за матеріалами аналізу уроків готував доповіді на теми: «Індивідуальний підхід до учнів у процесі навчання», «Підготовка вчителя до системи уроків», «Наочність у викладанні уроків», «Дидактична обробка матеріалу підручника під час підготовки до уроку» (Сухомлинський, 1977, Т. 4, с.70).

На основі відвіданих та проаналізованих уроків у початкових класах Василь Сухомлинський визначив їх структуру, дидактичні принципи, методи та завдання. На його думку, головне завдання початкового етапу навчання полягає в тому, щоб діти вміли читати, писати, думати, спостерігати, висловлювати свою думку. Важливе місце на уроках у початкових класах, наголошував педагог, повинні займати ті види робіт, які забезпечують єдність слова вчителя, наочного образу та практичної діяльності дітей: «Початковий етап навчання відкриває дітям перше вікно у світ, їм усе треба пояснювати, показувати, тлумачити, вчити робити» (Сухомлинський, 1977, Т. 4, с. 277). У початкових класах Павлиської школи особлива увага зверталась на техніку читання: вчителі навчали дітей зосереджуватися не на процесі читання, а на змісті прочитаного, адже «хто не вміє читати - не вміє мислити» (Сухомлинський, 1977, Т. 3, с. 431). Видатний педагог називав урок основою освітнього процесу, мета якого - забезпечити освітню, виховну та розвиваючу функції. Від якості уроків залежить не тільки міцність, глибина знань, а й виховання дитини. На думку Сухомлинського, на уроці надзвичайно важливий особистий приклад вчителя. Урок виховує не тільки змістом знань. Той самий зміст знань в одного вчителя виховує, а в іншого - не виховує. Виховна сила знань залежить значною мірою від того, наскільки тісно зливаються знання 3 особистим духовним світом педагога... (Сухомлинський, 1977, Т. 4, с. 576).

Урок завжди був у центрі професійної уваги i турботи Василя Сухомлинського. Він вважав, що відвідування й аналіз уроків - це найважливіший обов'язок директора школи, і ставив собі за мету впродовж навчального року відвідати в кожного вчителя по 10-12 уроків, адже від повсякденного їх удосконалення, що відбувається завдяки вдумливому аналізу керівника, залежить культура всього педагогічного процесу в школі. Від уроку йдуть десятки непомітних, на перший погляд, ниточок до позакласної роботи, до самовиховання школярів, до індивідуальної творчої лабораторії вчителя, до обміну досвідом, до роботи педагогічного колективу з батьками тощо. На уроці можна побачити сильні й слабкі сторони як позакласної роботи, так і педагогічної освіти батьків та виховання учнівського колективу. Я зробив для себе правилом: поки не побував на двох уроках, вважаю, що сьогодні в школі нічого не зробив... (Сухомлинський, 1977, Т. 4, с. 577).

Багаторічні спостереження за роботою керівників шкіл переконали Василя Сухомлинського в тому, що поверховість, примітивізм керівництва - це насамперед наслідок того, що директор не знає, що робиться на уроках, в якому напрямі розвивається творча майстерність учителів, та й чи є вона взагалі у школі, ця майстерність.

Головна мета відвідування та аналізу уроку, на думку Василя Олександровича, - дослідити, як розкривається на уроці інтелектуальне життя педагога, його кругозір і духовні інтереси. Саме на уроці він бачив, чим живе вчитель, що він читає, яке місце в його духовному житті посідає книга, як він стежить за досягненнями науки і здобутками культури. Сухомлинський як мудрий директор і наставник звертав увагу своїх колег на недоліки уроків, серед яких - невміння чітко визначати мету й окреслити основні етапи, марнотратство на першому етапі уроку й під час перевірки домашнього завдання. Відвідуючи й аналізуючи уроки в початкових класах, педагог звертав увагу вчителів на те, чи проводяться заняття з розвитку мови серед природи. Якщо цих занять немає - це серйозний сигнал про відрив навчання від виховання розумових здібностей. Необхідно показати вчителеві, як проводити уроки серед природи, як учити дітей думати (Сухомлинський, 1977, Т. 4, с. 590).

Василь Олександрович визначив головний критерій оцінки уроку - міцні знання всіх без винятку учнів. Щоб цього досягти, він радив учителям ураховувати вікові та індивідуальні психологічні особливості молодших школярів, зазначав, що для деяких учителів психологія дітей, їхній внутрішній світ - це книга за сімома печатями. Педагог радив учителям створювати атмосферу радості та інтелектуального успіху, виховувати в дітей почуття емпатії. Як заповіт педагогам звучать його слова: «Бережіть дитячий вогник допитливості, жадоби до знань. Єдиним джерелом, яке живить цей вогник, є радість успіху в праці. Винагороджуйте 
кожне подолання труднощів заслуженою оцінкою...» (Сухомлинський, 1977, Т. 3, с. 176).

У контексті тих змін, які відбуваються сьогодні в організації освітнього процесу, особливої уваги заслуговують поради видатного педагога щодо оцінювання знань учнів. Так, Василь Сухомлинський зауважував: «Лихо багатьох учителів у тому, що вони вимірюють і оцінюють духовний світ дитини тільки оцінками, ділять усіх учнів на дві категорії, залежно від того, учать або не учать діти уроки». Василь Олександрович радить учителям оцінювати розумову працю дитини навіть тоді, коли вона відзначається навіть незначними позитивними успіхами. Покарання незадовільною оцінкою особливо боляче ранить, ображає і принижує гідність дитини: «Не ловіть дітей на незнанні, оцінка - не покарання, оцінка - радість» (Омельчук, 2018, c. 73,74$)$.

Під час відвідування уроків Василь Олександрович особливу увагу звертав на психологічну культуру вчителя. Щоб успішно навчати дітей, вважав він, необхідно грунтовно вивчити їхні індивідуальні особливості, сприймання, відчуття, увагу, пам'ять, мовлення, уяву, темперамент, здібності, а також добре знати сім’ю учня. Ці поради педагога-новатора неабияк актуальні й тепер, коли перед учителем початкових класів постає досить непросте завдання - визначити готовність дитини до навчання в школі. Відсутність індивідуального підходу до розумової праці він вважав причиною появи невстигаючих учнів: «Немає абстрактного учня, до якого можна було б механічно застосувати всі закономірності навчально-виховного процесу. А це означає, що в навчанні має бути індивідуалізація - і в змісті розумової праці, і в часі (Онишків, 2008, с. 4, 5).

На окрему увагу в контексті Концепції Нової української школи заслуговує і досвід В. Сухомлинського щодо проведення уроків у Школі під блакитним небом. У зв'язку з цим він зазначав: «Природа мозку дитини потребує, щоб їі розум виховувався біля джерела думки - серед наочних образів, передусім серед природи, щоб думка переключалася з наочного образу на «обробку» інформації про цей образ» (Сухомлинький, 1977, Т. 3, c. 34). Уроки серед природи, на свіжому повітрі, під блакитним небом мали виняткове значення для дітей. Під час таких уроків діти почувалися бадьорими і життєрадісними, ніколи не йшли додому з важкою головою. Щотижня кілька уроків учителі у Павлиській школі присвячували «подорожам» до джерел думки й рідного слова - спостереженням. Розповіді про природу, предмети і явища навколишнього світу пробуджували в учнів допитливість, а вчителям доводилося відповідати на безліч дитячих запитань: «Чому рано-вранці сонце червоне, а опівдні - вогнисте?», «Чому соняшник повертає квітку за сонцем, хіба він бачить, як людина?», «Що таке веселка?» тощо (Сухомлинський, 1977, T. 3, c. 121, 122).

Подорожі, спостереження у Школі радості збагачували думку, сприяли розвиткові мислення, уяви і мовлення школярів. Спостереження за природними явищами в початковій школі - це могутній фактор розвитку дитини. Завдяки спостереженням не тільки здобуваються знання, вони застосовуються як інструмент у праці. Якщо повторення - мати навчання, то спостереження - мати осмислення й запам'ятовування знань. Спостережливий учень ніколи не буває невстигаючим. У початкових класах уроки мислення, спостереження під блакитним небом необхідні дитині, як сонце, повітря й волога необхідні рослинам. Завдяки їм діти навчаються бачити у звичайному - незвичайне, вибудовуючи причинно-наслідкові зв'язки (Омельчук, 2018 , c. 43,44$)$

Без емоційного ставлення до знань, без інтересу, подиву, задоволення, без радості, захоплення, впевненості та інших позитивних переживань, зазначав В. Сухомлинський, навчання неможливе. Учитель повинен не байдуже, не формально «подавати матеріал», а звертатися до живої думки й почуттів учнів. Тобто педагог вимагав не пріоритету емоцій, а злиття думки, «гармонії розуму і серця», в якій, за його твердженням, серцю належить найтонша, найніжніша мелодія (Омельчук, 2018, с. 50).

Його величність урок, що пробуджує не тільки розум дитини, а й торкається іiї серця, - саме такий урок повинен завітати до кожної Нової української школи разом із мудрими порадами й настановами Василя Олександровича. За цих умов для кожного вчителя, зокрема і початкових класів, девізом у професійній діяльності мають стати слова видатного педагога: «Неможливо уявити педагога без любові до дитини, так само, як неможливо уявити співака без слуху чи живописця без відчуття кольору» (Омельчук, 2018, с. 6).

Висновки. Педагогічна спадщина Василя Сухомлинського не має терміну давності. Унікальність його педагогічного досвіду, творчий підхід до теорії і практики навчання й виховання, особистісної орієнтації навчання, $\epsilon$ не лише цінним внеском у вітчизняну та світову скарбницю педагогічної думки, а й вважаються фундаментом сучасної освітньої системи (Мельник, 2019 , с. 132). Його психолого-дидактичні поради неабияк розкривають освітні можливості уроку в сучасній початковій школі. Педагогічний досвід та багата педагогічна спадщина видатного педагога-новатора має стати для сучасних учителів, керівників закладів освіти тим резервом, що сприятиме вдосконаленню якості Нової української школі.

Перспективи подальших досліджень. Представлена робота не претендує на статус глибокого та всебічного дослідження. Вона окреслює лише окремі положення дидактичної системи Василя Сухомлинського, що потребує більш грунтовного вивчення, узагальнення й упровадження в сучасній школі. У наших подальших розвідках плануємо дослідити дидактичні умови розвивального навчання в педагогічній спадщині Василя Сухомлинського.

\section{СПИСОК ВИКОРИСТАНОӤ ЛІТЕРАТУРИ}

Омельчук, В. В. (2018). Педагогіка Василя Сухомлинського - педагогіка гуманізму. Рівне: Волинські обереги. С. $64,6,73,74,43,44,50$.

Сухомлинський, В. О. (1977). Розмова з молодим директором школи. Вибрані твори: в 5 т. Київ: Радянська школа. Т. 4. С. 277, 405, 590, 576, 577, 580.

Сухомлинський, В. О. (1977). Павлиська середня школа. Вибрані твори: в 5 т. Київ: Радянська школа. T. 4. C. $70,277$. 
Сухомлинський, В. О. (1977). Народження громадянина. Вибрані твори: в 5 т. Київ: Радянська школа. T. 3. C. 431.

Сухомлинський, В.О. (1977). Серце віддаю дітям. Вибрані твори: в 5 т. Київ: Радянська школа. Т. 3. С. 34, $121,122,176$.

Онишків, 3. (2008). В. О. Сухомлинський про індивідуалізацію навчально-виховного процесу в початкових класах. Початкова школа. № 6. С. 4, 5.

Мельник, Н. (2019). Методичні ідеї педагогічної системи Василя Сухомлинського. Нова педагогічна думка. Рівне: РОІППО. № 3 (99). С. 127-133.

\section{REFERENCES}

Omelchuk, V. V. (2018). Pedahohika Vasylia Sukhomlynskoho - pedahohika humanizmu [Vasyl Sukhomlynsky's Pedagogy Is the Pedagogy of Humanism]. Rivne: Volynski oberehy. S. $64,6,73,74,43,44,50$. [in Ukrainian].

Sukhomlynskyi, V. O. (1977). Rozmova z molodym dyrektorom shkoly [Conversation with a Young School Principal]. Vybrani tvory: v 5 t. Kyiv: Radianska shkola. T. 4. S. 277, 405, 590, 576, 577, 580. [in Ukrainian].
Sukhomlynskyi, V. O. (1977). Pavlyska serednia shkola [The Pavlysh Secondary School]. Vybrani tvory: v 5 t. Kyiv: Radianska shkola. T. 4. S.70, 277. [in Ukrainian]. Sukhomlynskyi, V. O. (1977). Narodzhennia hromadianyna [Birth of a Citizen]. Vybrani tvory: v 5 t. Kyiv: Radianska shkola. T. 3. S. 431. [in Ukrainian].

Sukhomlynskyi, V. O. (1977) Sertse viddaiu ditiam [My Heart I Give to Children]. Vybrani tvory: v 5 t. Kyiv: Radianska shkola. T. 3. S. 34, 121, 122, 176. [in Ukrainian]. Onyshkiv, Z. (2008). V. O. Sukhomlynskyi pro indyvidualizatsiiu navchalno-vykhovnoho protsesu v pochatkovykh klasakh [V. O. Sukhomlynsky on the Individualization of the Educational Process in Primary School]. Pochatkova shkola. № 6. S. 4, 5. [in Ukrainian].

Melnyk, N. (2019). Metodychni idei pedahohichnoi systemy Vasylia Sukhomlynskoho [Methodical ideas of Vasyl Sukhomlynsky pedagogical system]. Nova pedahohichna dumka. Rivne: ROIPPO. № 3 (99). S. 127-133. [in Ukrainian].

Дата надходження до редакиіï: 18.03.2021 p. 